\title{
S1-12
} 単離腫瘍灌流実験系を用いた腫瘍内直接注入後の 薬物移行動態解析

\author{
$\bigcirc$ 野村 武彦、高倉 喜信、橋田 充 \\ 京都大学大学院薬学研究科薬品動態制御学分野

\section{PHARMACOKINETIC ANALYSIS OF DRUG DISPOSITION AFTER INTRATUMORAL INJECTION IN TISSUE-ISOLATED TUMOR PERFUSION SYSTEM}

\section{Takehiko NOMURA, Yoshinobu TAKAKURA, and Mitsuru HASHIDA Department of Drug Delivery Research, Graduate School of Pharmaceutical Sciences, Kyoto University, Kyoto 606-01}

【目的】癌化学療法あるいは遺伝子治療におい て、薬物の腫瘍内直接投与は腫瘍ターゲティン グの有用な方法の一つと考えられるが、注入さ れた薬物の腫瘍内動態に関する情報は極めてそ しい。そこで我々は、腫瘍内のみの薬物動態が 評価可能な単離腫瘍灌流実験系を用い、まず抗 癌剂や遺伝子医薬品を投与した際の動態につい て検討した。さらに腫瘍内滞留性を改善するた め、抗癌剤に対しては高分子化抒よび微粒子化 した場合、また遺伝子医薬品に対しては、カチ オン性リポソームをキャリアーとして用いた場 合の腫瘍内動態に与える影響ついても調へ、抗 癌剂に代表される低分子に始まり遺伝子のよう な巨大高分子にいたる薬物の、腫瘍内直接投与 後の移行動態に及ぼす分子サイズ、電荷といっ た物理化学的性質の影響について整理した。 【実験方法】対象薬物およびキャリアー：低分 子抗癌剤として mitomycin C (MMC) を選択し、 その高分子化プロドラッグとしてMMC-dextran 結合体 (分子量約 7万、MMC-Dcat, -Dan) を合 成した。微粒子性製剂には、粒子径と電荷の異 なる 4 種の liposome および emulsion を調製し た。さらに、遺伝子医薬品としてモデルプラス ミドDNA（pCAT）を用い、遺伝子導入用キャ リアーである cationic liposome (Lipofectin) との 複合体についても検討した。ラット単離腫瘍灌 流実験: 単離腫瘍標本および灌流実験は、既報 1)の方法に従って行った。薬液注入後、静脈側 流出液を 2 時間まで経時的にサンプリングし流 出量を定量した。また、灌流中に腫瘍表面から 漏出する液をシャーレ上に採取し漏出液中の量 と、実験終了時における腫瘍内残存量も併せて
測定した。速度論的腫瘍内動態解析: 腫瘍内直 接注入後の薬物の静脈側流出曲線を速度論的に 解析し、組織内での移行速度を表す各パラメー 夕を誘導した。解析に当たっては、腫瘍組織を 大きく2つのコンパートメントに分けたモデル (Fig. 1) を構築し、これに基づいて理論式を得た 上で、非線形最小二乗法プログラム MULTIを 用い、静脈側流出パターンに対してあてはめを 行うことで各パラメー夕を算出した。
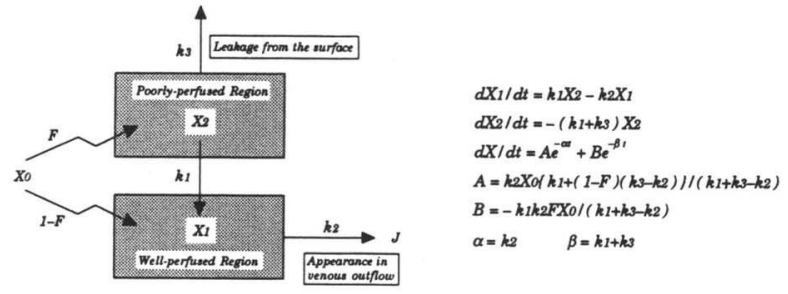

$k 1:$ Rate constant of transefer from poorly-pertued
region to teell. perfused negrion $(1 / \mathrm{min})$ $k z$ : Venous appearance rate constant $(/ m$ min $k s$ : Rate constant of leakage from the surface

$X_{0}:$ Injected dose (100\%)
$X_{1}:$ Drug amount in well-perfused region (\% of dose) $X_{1}$ : Drug amount in well.perfused region (\% of dose)
$X_{2}:$ Drug amount in poorly-perfused region (\% of dose)
$J$ :

Fig. 1 Pharmacokinetic model for analysis of drug disposition after intratumoral injection.

【結果及び考察】

低分子薬物の高分子化の影響 2)：MMC 単独で は、投与後 2 時間までに投与量の約 $80 \%$ が静 脈側に回収され、腫瘍内残存はほとんど認めら れなかった。これに対して、MMC-Dを投与し た場合、2 時間までの腫瘍内滞留性は MMCに 比べ有意に向上したことから、高分子化により 腫瘍組織側から血管側への移行が抑制されてい ることが示唆された。また、その割合は、正電 荷をもつ MMC-Dcatの方がMMC-Danよりも高 かったことから、薬物と腫瘍組織との静電的相 互作用の関与が示された (Fig. 2)。微粒子性製 剂：平均粒子径約 $85 \mathrm{~nm}$ の small emulsion では 投与量の約 $40 \%$ 、粒子径約 $120 \mathrm{~nm}$ の neutral 
liposome では約 $10 \%$ 程度の腫瘍内残存量で あったのに対し、粒子径約 $250 \mathrm{~nm}$ の large emulsionでは、2時間後においても約 $70 \%$ 近く

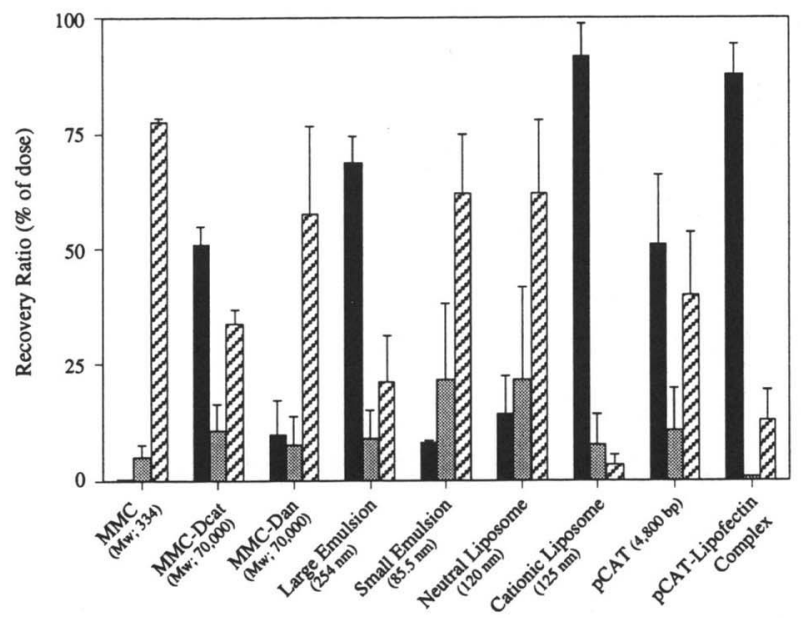

Fig. 2 Recovery ratio of various drugs and carriers $2 \mathrm{hr}$ after intratumoral injection into perfused tissue-isolated tumors. Results are expressed as the mean $\pm \mathrm{S}$. E. of at least three experiments. Remaining in the tumor tissue (closed bar), leakage from the tumor surface (grey bar), recovery in venous outflow (hatched bar).

が腫瘍内に滞留した。また、 cationic liposomeで は、粒子径が neutral liposome と同程度にもかか わらず、投与量の約 $60 \%$ 近くが腫瘍内に残存 した (Fig. 2)。遺伝子医薬品 ${ }^{3}$ ： pCAT 単独の腫 瘍内残存量は投与量の約 $50 \%$ であったのに対 し、Lipofectin との複合体では約 $90 \%$ となり静 脈側流出量も僅かであった。これらの結果か ら、カチオン性リポソームによってプラスミド DNA 自身の腫瘍内滞留性が改善されることが 明らかとなった (Fig. 2)。速度論的解析：以上、
分子 (粒子) サイズや電荷といった物理化学的 性質の異なる物質の局所投与後の静脈側流出パ ターンをモデル解析した結果、数 nm から数百 $\mathrm{nm}$ の物質の腫瘍組織側から血管側への移行速 度 $\left(k_{2}\right)$ は低分子のそれと大きな違いはなく、電 荷の影響も小さいことが示された。これに対 し、投与部位から血管近傍への腫瘍組織内移行 過程 $\left(k_{1}\right)$ においては、サイズゃ電荷の影響を 大きく受け、特にサイズの増大 $(>250 \mathrm{~nm})$ あ るいは正電荷を付与することにより移行が抑制 され、腫瘍内滞留性が向上することが明らかと なった (Fig. 3)。

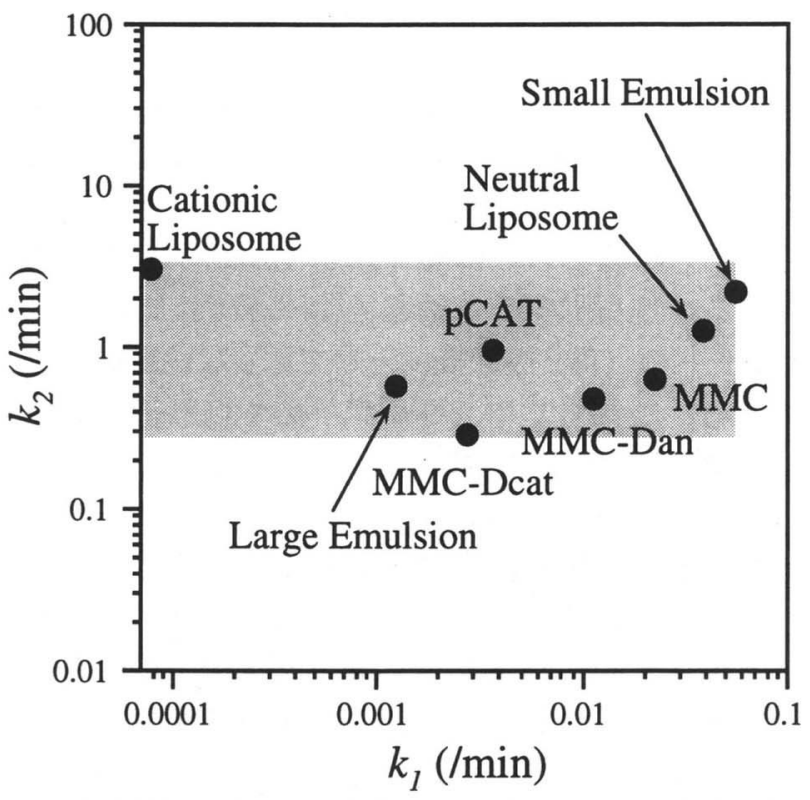

Fig. 3 Effect of size and charge on intratumoral behavior of various drugs and carriers after intratumoral injection into tissue-isolated tumors.

【ABSTRACT】 In cancer therapy, intratumoral injection is an effective way to maximize the action of injected substances at the tumor site, however there is little information on the disposition characteristics of the injected materials after intratumoral injection. To clarify the effect of molecular size and surface charge of various drugs and carriers in the tumor at an organ level, their pharmacokinetic properties after intratumoral injection were studied in the perfusion experiments employing the tissue-isolated tumor preparation. Pharmacokinetic analysis of their venous outflow patterns revealed that alteration of the physicochemical properties of drugs and carriers dominantly changed the rate of transfer from the poorly-perfused region to the well-perfused region, suggesting that this process is the determinant factor which alters the intratumoral behavior of drugs and carriers after direct injection.

\section{【REFERENCES】}

1) A. Saikawa, T. Nomura, F. Yamashita et al. Pharm. Res. 13: 1438-1444 (1996).

2) T. Nomura, A. Saikawa, S. Morita et al. J. Control. Rel. submitted.

3) T. Nomura, S. Nakajima, K. Kawabata et al. Cancer Res. 57: 2681-2686 (1997). 